\title{
Evaluation of Family Physicians' Opinions on Defensive Medicine Practices: The Case of the Province of Isparta/Turkey
}

\author{
Oğuzhan Yüksel ${ }^{1}$ (iD
}

${ }^{1}$ Sağlık Bakanlığı, Isparta Ağız ve Diş Sağlığı Merkezi, Isparta, Türkiye

Oğuzhan YÜKSEL, Dr.

Correspondence: Oğuzhan Yüksel

Sağlık Bakanlığı, Isparta Ağız ve Diş Sağlığı

Merkezi, Isparta, Türkiye

Phone: +902462330504

E-mail: oguzhan@doctor.com
Received : 25 March 2021

Accepted : 03 June 2021

\section{ABSTRACT}

Objective: In this descriptive study, the problems physicians are facing and their opinions on medical malpractice, which is frequently heard of today, were questioned. The purpose of this study was to determine family physicians' attitudes and knowledge towards defensive medicine practices.

Methods: The study was conducted by survey method in Isparta province in Turkey. In Isparta, 160 family doctors are employed within the Ministry of Health. The survey study was carried out during November-December 2020 with 77 family physicians who agreed to participate. Likert-type scale (strongly disagree, disagree, neither agree nor disagree, agree, strongly agree) was used to classify the answers. In addition, yes-no options were used for questions that measure knowledge level.

Results: Results showed that, of the 77 participants, 18 (23\%) did not hear of the concept of defensive medicine before, $48(62 \%)$ did not know enough about the content of the concept of defensive medicine, $5(6 \%)$ were sued for malpractice, 37 (48\%) thought that any lawsuit could be filed within the next 10 years. The attitude of "as malpractice cases are often reported in the media, I feel anxiety in medical practice" was highly prevalent among participants ( $n=46,59.7 \%)$ with this option recording the highest frequency of preference.

Conclusions: The results of the study showed that family physicians working in family health centers affiliated with the Ministry of Health are highly inclined on positive and negative defensive medicine practices.

Keywords: Defensive Medicine, Medical Malpractice, Family Physician

Defansif Tıp Uygulamalarında Aile Hekimlerinin Görüşlerinin Değerlendirilmesi: Isparta Illi Örneği

ÖZET

Amaç: Günümüzde sıkça duyulmaya başlanan tıbbi kötü uygulamalar (malpraktis) hakkında hekimlerin karşılaştıkları problemler ve bakış açllarını sorgulayan tanımlayıı nitelikteki bu araştırmada, aile hekimlerinin defansif tıp uygulamalarında sergiledikleri tutum ve bilgilerinim belirlenmesi amaçlanmıştır.

Gereç ve Yöntem: Çalışma Türkiye'deki Isparta ilinde, anket yöntemiyle yapılmıştır. Isparta'da, Sağlık Bakanlığı bünyesinde 160 aile hekimi görev yapmaktadır. Çalışmaya katılmayı onaylayan ve eksiksiz yanıtlayan 77 aile hekimi ile anketler gerçekleştirilmiştir. Sorulara verilen yanıtlar için, Likert tipi durum ölçme ifadeleri (tamamen katılıyorum, çok katılıyorum, orta derecede katılıyorum, az katılıyorum, hiç katılmıyorum) kullanıımıştır. Ayrıca bilgi düzeyini ölçen sorular için ise evet-hayır şıklarından yararlanılmışır.

Bulgular: Çalışma sonucunda aile hekimlerinden 18'i (\%23) daha önce defansif tıp kavramını duymadığını, 48'i (\%62) defansif tıp uygulamaları kavramının içeriğini yeterince bilmediğini, 5'i (\%6) malpraktis nedeni ile kendisine dava açıldığını, 37'si (\%48) önümüzdeki 10 yıl içerisinde herhangi bir dava açlabileceğini düşündüklerini ifade etmişlerdir. Malpraktis davaları medyada fazlaca yer buldukça mesleğimi icra ederken tedirginlik hissediyorum diyen aile hekimlerinin oranı ( $n=46, \% 59,7)$; tutum ölçen sorular arasında en büyük yüzdeye sahip olan seçenek olarak ilk sırada çıkmıştır.

Sonuç: Bu araştırmada elden edilen sonuçlar, Sağık Bakanlığı́na bağıı aile sağlığı merkezlerinde çalışan aile hekimlerinin önemli oranda pozitif ve negatif defansif tıp uygulamalarına yöneldiğini göstermektedir.

Anahtar Kelimeler: Defansif Tıp, Tibbi Malpraktis, Aile Hekimi 
T he concept of human rights gaining broader meaning worldwide, rapid progress in medical technologies, an increase in the desire of patients to seek their rights, and legal changes, all resulted in development of the concept of patient rights. Medical malpractice and defensive medicine have been shaped in parallel with these developments. Physicians have narrowed their treatment options in risky cases with the instinct to protect themselves and have consciously or unconsciously started using defensive medicine practices.

The concept of defensive medicine, also referred as cautious medicine in the literature, emerged in America in the 1970s. Defensive medicine can be defined as the various behaviors (requesting unnecessary medical tests for diagnosis and treatment, avoiding high-risk medical interventions, etc.) physicians do to protect themselves against criminal cases (1). Since the beginning of the 21 st century, the concept of medical law in Turkey has developed very rapidly. Amendments to Turkish criminal law passed in 2005 , lead to different practices in the legal responsibilities of forensic medicine and physicians. Such laws, which are not peculiar to Turkey, are also practiced in other countries (2).

Medicine and its minor branches can easily lead to human rights violations. In retrospect, it can be said that some human rights violations were effective in the emergence of the concept of patient rights (3). Recently, the concept of patient rights has been discussed in a broader context, both in the health sector and in the media, turning patient-physician relations and patient experiences during the process of healthcare into an area of interest for lawyers. In the Turkish healthcare system, first-contact primary care is delivered in community-based family health centers. The primary care team members working in these family health centers know the patient-family-environment and regional factors the best. Therefore; family physicians have a great responsibility in the management of first contacts, including diagnostic and treatment procedures.

The Ministry of Health (MoH) of The Republic of Turkey (2020) defines family physicians as follows: "Physicians (specialists of family medicine or practitioners who as part of the primary health care reform, received in-service training organized by the $\mathrm{MoH}$ ) who provide preventive health services for the person and primary care diagnostic, therapeutic and rehabilitative health services (without distinction of age, gender and disease) and provide mobile health services when necessary" (4). Initiative aimed at creating healthy societies rely on empowered family medicine and primary care. Which one is more meaningful? to give a Hepatitis $B$ vaccine to healthy individuals at the appropriate time, or to give a liver transplantion to a patient with cirrhosis due to hepatitis B infection? It can easily be seen that contrary approaches are also financially unsustainable (5).

The following examples can be given for physicians' defensive medical behaviors (6):

- Prescription of unnecessary drugs,

- Increase in diagnostic tests,

- Requesting more consultation for diagnosis and treatment,

- Keeping a more detailed record (in a way that does not comply with the anamnesis of the patient concerned).

In the code of professional ethics of the Turkish Medical Association, malpractice is defined as follows: "Harming a patient due to lack of knowledge, inexperience or apathy, and poor practice of medicine" (7). When the literature is reviewed, it is seen that defensive medicine is divided into two as positive and negative. Positive defensive medicine (PDM) involve supplying additional services of marginal or no medical value with the aim of reducing adverse outcomes, deterring patients from filing malpractice claims, or persuading the legal system that the standard of care was met. Negative defensive medicine (NDM), on the other hand, reflect physicians' efforts to distance themselves from sources of legal risk. Defensive medicine, particularly avoidance behavior, encompasses both day-to-day clinical decisions affecting individual patients and more systematic alterations of scope and style of practice (8). Examples for PDM applications can be given as; requiring extra analysis-x-ray, unnecessary observation, whereas examples for NDM applications can be given as; failure to perform risky surgical practices, avoiding surgery and redirecting patients to other healthcare facilities.

According to $\mathrm{MoH}$, in 2018, there were 26,252 family medicine units in Turkey, and the average population per unit was 3,124 people. In Isparta, the average population per family doctor was 2,848 people, which was lower than the national average. The number of visits to family medicine 
units in Turkey in 2018 was $258,436,607$. In the same period, the number of patients admitted to hospitals offering second and tertiary care services was 517,018,981 (9).

Fear of being prosecuted, positive or negative effects of media organizations, miscommunication, motivation for extra earning, healthcare policy and organisation of health care, the desire to be a famous physician are the reasons for defensive medicine behavior (10). Although defensive medicine has been looked into in the past in the USA and Europe and is still an up-to-date research topic, it has not yet been studied much in developing countries (11). The purpose of this study was to portray the views of family physicians who are per definition responsible for preventive care, on defensive medicine.

\section{MATERIAL AND METHODS}

Ethical approval was obtained from the Ethics Board of Suleyman Demirel University with a decision dated 30.09.2020 and numbered 45/2. In addition, a letter of permission to carry out this study was obtained from the Isparta Provincial Health Directorate (dated 20.10.2020 reference number 16657963-799). A descriptive survey study was conducted in Isparta/Turkey. There are a total of 160 family physicians working in family health centers in the universe. For enrolment, all of those family physicians were attempted to be contacted face-to-face or by phone, and a total of 77 family physicians participated (response rate $48.1 \%$ ). The surveys were conducted between November $1^{\text {st }}$ and December $31^{\text {st }}, 2020$. Due to time and cost constraints (i.e. the difficulty of reaching all family physicians throughout Turkey) the survey was applied only to physicians working in Isparta. The data includes subjective responses of family physicians who answered the questionnaire through their professional experience.

The survey used in the research consists of 3 parts. Sociodemographic characteristics (gender, marital status, whether to have children, expertise in medicine, age, professional experience period, average number of patients per day) are included in the first section. In the second part, the Defensive Medicine Attitude Scale was used to measure the physicians' behaviors. A section prepared to measure the attitudes of physicians to defensive medicine consists of PDM and NDM questions. 5 Likert-type status meter options were used to organize survey questions. The validity and reliability study of the Turkish version of the Defensive Medicine Attitude Scale was made by Başer et al. (12). In the third section, there are questions about the level of knowledge and case status of physicians in defensive medicine and malpractice.
Data were analyzed with SPSS 20.0 program. Descriptive statistics were calculated as mean, standard deviation, frequency, minimum, maximum. In addition, Factor Analysis, Pearson ChiSquare, Fisher Exact, Independence Samples $T$ and One-Way Anowa tests were used. Significance was evaluated at the $p<0.05$ level.

\section{RESULTS}

A total of 77 family physicians affiliated with the Isparta Provincial Health Directorate filled out a survey within the scope of the study. Fiftysix physicians (73\%) were male and $21(27 \%)$ were female. The average age was $43.02 \pm 8.61$ years (min:27, max:62). It was found that the average year of professional experience in the patient-physician relationship was $17.75 \pm 8.29$ years (min:2, max:33). Sixtysix participants were $(85.7 \%)$ practitioners and 11 participants $(15.6 \%)$ were specialized in family medicine. Twentynine (37.7\%) family physicians declared that they had 50 and more patient visits daily. Most of the participants $(84.4 \%$, $\mathrm{n}=65$ ) had children. Cronbach's Alpha reliability value of the applied survey was 0.758 . In Table 1, demographic data are shown in detail.

\begin{tabular}{|l|l|l|l|l|l|l|l|l|}
\hline \multicolumn{7}{|l|}{ Table 1. Demographic data of family physicians ( $=77)$} \\
\hline Gender & $\mathrm{n}$ & $\%$ & $\begin{array}{l}\text { Marriage } \\
\text { Status }\end{array}$ & $\mathrm{n}$ & $\%$ & $\begin{array}{l}\text { Specialty } \\
\text { Status }\end{array}$ & $\mathrm{n}$ & $\%$ \\
\hline Male & 56 & 72.7 & Married & 68 & 88.3 & $\begin{array}{l}\text { Medical } \\
\text { Practitioner }\end{array}$ & 66 & 85.7 \\
\hline Female & 21 & 27.3 & Single & 9 & 11.7 & $\begin{array}{l}\text { Specialist } \\
\text { Physician }\end{array}$ & 11 & 15.6 \\
\hline $\begin{array}{l}\text { Professional } \\
\text { Experience } \\
\text { (Year) }\end{array}$ & $\mathrm{n}$ & $\%$ & Age & $\mathrm{n}$ & $\%$ & $\begin{array}{l}\text { Number of } \\
\text { Patients Per } \\
\text { Day }\end{array}$ & $\mathrm{n}$ & $\%$ \\
\hline$\leq 9$ & 14 & 18.2 & $\leq 29$ & 8 & 10.4 & $10-30$ & 17 & 22.1 \\
\hline $10-19$ & 31 & 40.3 & $30-39$ & 20 & 26.0 & $30-50$ & 31 & 40.3 \\
\hline$\geq 20-$ & 32 & 41.6 & $40-49$ & 27 & 35.1 & $\geq 50-$ & 29 & 37.7 \\
\hline & & & $\geq 50-$ & 22 & 28.6 & & & \\
\hline
\end{tabular}

The first 6 questions in the survey are covering issues of PDM. Of the physicians participating in the study, $37.66 \%$ $(n=29)$ of the "In order to protect myself from legal problems, I ask my patients for medical tests other than what I consider necessary." question and $42.86 \%(n=33)$ of the "In order to protect myself from legal problems, I prescribe most of the appropriate medications within their indications to my patients." question gave the answers neither agree nor disagree. Nearly one in ten participants $(7.79 \%$, $\mathrm{n}=6$ ) strongly agreed with the statement "I want more consultation to protect myself from legal problems.." 
Family physicians who participated in the study strongly disagreed to the statements "I explain medical treatment procedures to my patients in more detail in order to protect them from legal problems.", "I keep the patient records in more detail in order to protect myself from legal problems." and "As malpractice cases are often reported in the media, I feel anxiety in medical practice.". Nearly $40 \%(37.66 \%, n=29)$ of family physicians neither agreed or disagreed with the statement "I devote more time to my patients to protect myself from legal problems." The last 5 items in the survey are NDM questions. One out of ten participants $(10.39 \%, n=8)$ stated that they strongly disagreed with the "In order to protect myself from legal problems, I avoid patients who are likely to sue and patients with complex medical problems." statement. Nearly half of the participants $(46.75 \%, n=36)$ agreed to the statement "I avoid treatment with a high complication rate to protect myself from legal problems.". Thirteen percent $(12.98 \%, \mathrm{n}=10)$ of family physicians disagreed or strongly disagreed to the "In order to protect myself from legal problems, I tend to prefer non-invasive rather than surgical treatments." statement. The distribution of the answers given to the survey is shown in Table 2 .
The answers given to the questions measuring the knowledge level of family physicians about defensive medicine are shown in Table 3. As can be seen from the table, the vast majority of family physicians $(93.51 \%, \mathrm{n}=72)$ answered no to the "Have you been prosecuted for medical malpractice?" question. In addition, almost half (48.05\%, $\mathrm{n}=37$ ) of family physicians answered the "Do you think that in the next 10 years, any lawsuits can be filed against you for medical malpractice?" question with yes. Nearly eight out of ten $(76.62 \%, n=59)$ of family physicians stated that they had heard the concept of defensive medicine practices before. The majority $(62.34 \%, \mathrm{n}=48)$ stated that they do not have sufficient knowledge of the content of defensive medicine practices.

The Likert scale preferences to defensive medicine survey options; "strongly agree" were scored with 5 points and "strongly disagree" was scored with 1 point, individual scores for both sub-dimensions (PDM and NDM) were calculated for all participants. In the PDM subdimension, it was understood that family physicians exhibited an above-average (mean score: $3.39 \pm 0.60)$ PDM attitude. Based on this, it can be said that physicians have a defensive attitude (they want more tests and consultations, they approve most of the drugs to be prescribed within the indication, and they keep patients' records in more detail, etc.).

\begin{tabular}{|c|c|c|c|c|c|c|c|c|c|c|}
\hline \multirow[t]{2}{*}{ Questions } & \multicolumn{2}{|c|}{$\begin{array}{l}\text { Strongly } \\
\text { agree }\end{array}$} & \multicolumn{2}{|c|}{ Agree } & \multicolumn{2}{|c|}{$\begin{array}{l}\text { Neither } \\
\text { agree nor } \\
\text { disagree }\end{array}$} & \multicolumn{2}{|c|}{ Disagree } & \multicolumn{2}{|c|}{$\begin{array}{l}\text { Strongly } \\
\text { disagree }\end{array}$} \\
\hline & $n$ & $\%$ & $n$ & $\%$ & $n$ & $\%$ & $n$ & $\%$ & $\mathrm{n}$ & $\%$ \\
\hline $\begin{array}{l}\text { In order to protect myself from legal problems, I ask my patients for } \\
\text { medical tests other than what I consider necessary. }\end{array}$ & 8 & 10.39 & 15 & 19.48 & 29 & 37.66 & 17 & 22.08 & 8 & 10.39 \\
\hline $\begin{array}{l}\text { In order to protect myself from legal problems, I prescribe most of the } \\
\text { appropriate medications within their indications to my patients. }\end{array}$ & 8 & 10.39 & 22 & 28.57 & 33 & 42.86 & 10 & 12.99 & 4 & 5.19 \\
\hline I want more consultation to protect myself from legal problems. & 6 & 7.79 & 18 & 23.38 & 33 & 42.86 & 15 & 19.48 & 5 & 6.49 \\
\hline $\begin{array}{l}\text { I explain medical treatment procedures to my patients in more detail in } \\
\text { order to protect them from legal problems. }\end{array}$ & 24 & 31.17 & 27 & 35.06 & 22 & 28.57 & 4 & 5.19 & - & - \\
\hline I devote more time to my patients to protect myself from legal problems. & 8 & 10.39 & 27 & 35.06 & 29 & 37.66 & 9 & 11.69 & 4 & 5.19 \\
\hline $\begin{array}{l}\text { I keep the patient records in more detail in order to protect myself from } \\
\text { legal problems. }\end{array}$ & 18 & 23.38 & 32 & 41.56 & 22 & 28.57 & 5 & 6.49 & - & - \\
\hline $\begin{array}{l}\text { In order to protect myself from legal problems, I avoid treating patients } \\
\text { who are likely to sue. }\end{array}$ & 15 & 19.48 & 16 & 20.78 & 27 & 35.06 & 11 & 14.29 & 8 & 10.39 \\
\hline $\begin{array}{l}\text { In order to protect myself from legal problems, I avoid patients with } \\
\text { complex medical problems. }\end{array}$ & 8 & 10.39 & 22 & 28.57 & 25 & 32.47 & 14 & 18.18 & 8 & 10.39 \\
\hline $\begin{array}{l}\text { I avoid treatment with a high complication rate to protect myself from } \\
\text { legal problems. }\end{array}$ & 12 & 15.58 & 36 & 46.75 & 23 & 29.87 & 5 & 6.49 & 1 & 1.30 \\
\hline $\begin{array}{l}\text { In order to protect myself from legal problems, I tend to prefer non- } \\
\text { invasive rather than surgical treatments. }\end{array}$ & 10 & 12.99 & 33 & 42.86 & 24 & 31.17 & 6 & 7.79 & 4 & 5.19 \\
\hline $\begin{array}{l}\text { As malpractice cases are often reported in the media, I feel anxiety in } \\
\text { medical practice. }\end{array}$ & 46 & 59.74 & 19 & 24.68 & 8 & 10.39 & 4 & 5.19 & - & - \\
\hline
\end{tabular}


Table 3. Distribution of family physicians' knowledge of defensive medicine

\begin{tabular}{|l|c|c|c|c|}
\hline \multirow{2}{*}{} & \multicolumn{2}{|c|}{ Yes } & \multicolumn{2}{|c|}{ No } \\
\cline { 2 - 5 } & $\mathrm{n}$ & $\%$ & $\mathrm{n}$ & $\%$ \\
\hline $\begin{array}{l}\text { Have you been prosecuted for medical } \\
\text { malpractice? }\end{array}$ & 5 & 6.49 & 72 & 93.51 \\
\hline $\begin{array}{l}\text { Do you think any lawsuits can be filed } \\
\text { against you in the next 10 years? }\end{array}$ & 37 & 48.05 & 40 & 51.95 \\
\hline $\begin{array}{l}\text { Have you ever heard of the concept of } \\
\text { defensive medicine practices in the past? }\end{array}$ & 59 & 76.62 & 18 & 23.38 \\
\hline $\begin{array}{l}\text { Do you have enough information about } \\
\text { the content of defensive medicine } \\
\text { practices? }\end{array}$ & 29 & 37.66 & 48 & 62.34 \\
\hline
\end{tabular}

When the NDM sub-dimension is examined, again values above average (mean score: $3.58 \pm 0.74$ ) are noticeable. In short, family physicians avoid patients who may sue. It is understood they did not choose invasive treatments and were influenced by news of medical malpractice litigation in the press.

In the factor analysis of the defense medicine survey, factors with a preliminary value greater than 1 were evaluated and 4 factors were determined. Kaiser-Meyer-Olkin sampling adequacy $(\mathrm{KMO}=0.664)$ and Bartlett's test results $(p=0.000<0.05)$ were found at acceptable levels. Four factors accounted for $68 \%$ of the total change. The first factor had the highest weightening (24.3\%). Here; 7., 8., 9. and 10 . survey questions have a load of over 0.7 . There was no question with a load value less than 0.5. Efficiencies on the total change are shown in Table 4.

\section{Tablo 4. Factor analysis results}

\begin{tabular}{|l|c|c|c|c|c|}
\hline & \multicolumn{5}{|c|}{ Rotated Component Matrix } \\
\cline { 2 - 6 } & 1 & 2 & 3 & 4 & Extraction $^{\mathrm{a}}$ \\
\hline Question 1 & & .715 & & & .636 \\
\hline Question 2 & & & & .800 & .733 \\
\hline Question 3 & & .780 & & & .690 \\
\hline Question 4 & & & .779 & & .617 \\
\hline Question 5 & & .624 & & & .571 \\
\hline Question 6 & & & .708 & & .602 \\
\hline Question 7 & .737 & & & & .692 \\
\hline Question 8 & .861 & & & & .847 \\
\hline Question 9 & .832 & & & & .759 \\
\hline Question 10 & .755 & & & & .668 \\
\hline Question 11 & & & & .698 & .668 \\
\hline $\begin{array}{l}\text { Extraction Method: Principal Component Analysis. } \\
\text { Rotation Method: Varimax with Kaiser Normalization. } \\
\text { 6 iterations. }\end{array}$ & & & \\
\hline
\end{tabular}

In the independent sample T-test and One-way Anowa results, it was found that there was no significant difference between the scale scores in both gender and medical specialty variables. It was found that there was a statistically significant difference between marital status and scale scores. In addition, there was no statistically significant difference between professional experience and the average number of patients per day and scale scores. A positive correlation ( $r=0.324)$ was found between PDM and NDM.

\section{DISCUSSION}

When the findings of the study are examined, it is understood that family physicians exhibit above-average PDM and NDM behavior. In addition, 1 out of every 2 family doctors believes that in the next 10 years, a malpractice lawsuit can be filed against them.

Lawsuits filed as a result of faulty treatments increase the work of documenting and recording, rather than reducing procedures. If a group of physicians is inclined to defensive medicine, they have been sued in the past and have become sensitive to the value of careful documentation (13). Another study in the UK (Summerton-1995) found that $86 \%$ of physicians provide detailed explanations of treatment procedures. It was also highlighted that $29 \%$ made unnecessary prescribing of drugs, and 59\% requested medical diagnostic tests more often than required (6). In their study, Passmore and Leung (2002) reported that about three-quarters of psychiatrists exhibited defensive medical behavior in the last month (14).

Hiyama et al., (2006), conducted a study in Japan with 131 gastroenterologists. Nearly all (96\%) were found to avoid high-risk patients and their surgeries. Experienced gastroenterologists (those who have practiced their profession for more than 20 years) were, significantly less likely to display defensive medical behaviors than those in practice for less than 10 years. In addition, nearly all gastroenterologists (98\%) reported practicing defensive medicine (15).

Aynaci (2008) investigated the concept of defensive medicine with 762 physicians in Konya/Turkey. It has been found that physicians with medical malpractice insurance perform more defensive medical practices than those who do not. The rate of physicians using defensive medicine was found to be $78.38 \%$ (16). 
Baser et al. (2014); conducted a study where a defensive medicine survey was applied to family physicians in Izmir/ Turkey. It was understood that $21 \%$ (n:17) practiced high degree, $49.3 \%$ ( $\mathrm{n}: 40)$ practiced moderate degree, and $6.2 \%(n: 5)$ practiced weak degree of defensive medicine (12).

Ozata et al., (2018) they surveyed 173 physicians working in hospitals in Konya/Turkey. It was shown that $93.6 \%$ of physicians practice defensive medicine and are afraid of malpractice cases. In addition, physicians stated that they found medical malpractice insurance insufficient (11). In the results of this study, there is no family physician who says that I am not afraid of malpractice cases. All physicians are more or less concerned about malpractice cases.

A survey was conducted in Brazil with 104 physicians from 28 different specialties. It has been concluded that the results of defensive medicine and the knowledge of patients make the relationship between physician and patient even more difficult. Prolonging the process for diagnosing and treating the disease significantly increases the cost of health care. Seventy-five percent of respondents said they used defensive medicine daily (17).

In Konya/Turkey, the average defensive medicine attitudes of 207 physicians at the Faculty of Medicine were determined at a score of 3.27. Above average results were obtained in PDM and NDM. It has been found that male physicians use NDM practices more often than women. It was observed that those who practiced medicine for 5-10 years increased the use of defensive medicine compared to those over 11 years. Although physicians had previously heard of the concept of defensive medicine, they did not think they had sufficient knowledge (18). In this study, the average defensive medical attitudes score of physicians (3.48) was above average.

Another study was conducted in England (2013) with 204 physicians from 3 different hospitals. It has been found that $78 \%$ of physicians practice defensive medicine. Over half of the participants (59\%) said they often asked for unnecessary tests; $55 \%$ said they preferred to refer their patients to another specialist for a consultation. Nearly one out of ten participants in the U.K. study (9\%) said they refused treatment from high-risk patients (19). In this study, the ratio of family physicians who say they do not want unnecessary tests from their patients is only $10 \%(n=8)$. On the other hand, $31.1 \%(n=24)$ of family physicians stated that they strongly agree that they explain medical procedures in detail in order to protect themselves from legal problems.

In addition to all these, it is clear that unnecessary hospitalizations and observations damage health systems (14). The benefits of defensive medicine are controversial. Physicians can't know exactly what kind of behavior will be protective for them. There is almost no empirical evidence that medically unhelpful actions will reduce the risk of malpractice claims being made (20). The literature on defensive medicine has been examined and it has been observed that the results of the research show similarities with previous studies.

\section{CONCLUSIONS AND SUGGESTIONS}

Some physicians use the concept of defensive medicine consciously while others use it unconsciously. Considering the information asymmetry in the health field, defensive medicine emerges as an important current issue being studied.

The clear distinction between complications and malpractice will lead physicians to be more courageous in their treatment processes. Drugs or operational procedures can have side effects and complications in medicine, which is a risky profession. Physicians should not think whether patients would sue them or not, and it should be ensured that they examine and treat the patients without anxiety. This way, physicians will not request unnecessary analysis-x-rays and be afraid of risky practices.

While all precautions are taken, the existence of insurance and legal bases that support physicians and healthcare professionals in possible complications may play a role in preventing defensive medicine practices. Arranging the necessary planning for physicians to devote sufficient time for their patients will prevent errors that may arise from high work load. In the reporting of medical errors, physicians should be able to make objective feedbacks. In future studies, it may be recommended to examine the defensive medicine attitudes of physicians at higher level hospitals and private hospitals.

\section{REFERENCES}

1. Dedeoğlu AK. Özel hastanelerde çalışan hekimlerin tıbbi müdahale ve tedavide malpraktisten doğan hukuki ve cezai sorumluluklarına ilişkin farkındalık düzeylerinin ölçümü: Ankara ili özel hastaneler uygulaması [Yüksek Lisans Tezi]. Atılım Üniversitesi Sosyal Bilimler Enstitüsü. Ankara; 2012. 
2. Altun G, Yorulmaz AC. Yasal değişiklikler sonrası hekim sorumluluğu ve malpraktis. Trakya Üniversitesi Tıp Fakültesi Dergisi. 2010; 27(1), 7-12.

3. Tacir H. Hastanın kendi geleceğini belirleme hakkı. [Doktora Tezi]. Marmara Üniversitesi Sosyal Bilimler Enstitüsü. İstanbul; 2010.

4. Türkiye Cumhuriyeti Sağlık Bakanlığı (Ministry of Health of The Republic of Turkey). Halk Sağlığı Genel Müdürlüğü, Aile Hekimliği Dairesi Başkanlığı [Internet]. [cited 2020 Sep 25]. Available from: https://hsgm.saglik.gov.tr/tr/ailehekimligi-anasayfa.html

5. Üstü $Y$, Uğurlu M. Bir analiz: Aile hekimliği ülkemizde etkin kullanılıyor mu? Ankara Medical Journal. 2015; 15(4), 244-248.

6. Summerton N. Positive and negative factors in defensive medicine: A Questionnaire study of general practitioners. Bmj. 1995; 310(6971), 27.

7. TürkTabipler Birliği (1999). Hekimlik Meslek Etiği Kuralları, [Internet]. [cited 2020 Oct 10]. Available from: https://www.ttb.org.tr/mevzuat/ index.php?option=com_content $\&$ task=view\&id=65\&ltemid=31

8. Studdert DM, Mello MM, Sage WM, DesRoches CM, Peugh J, Zapert $\mathrm{K}$, Brennan TA. Defensive medicine among high-risk specialist physicians in a volatile malpractice environment. Journal of the American Medical Association. 2005; 293(21), 2609-2617.

9. Türkiye Cumhuriyeti Sağlık Bakanlığı. Sağlık istatistikleri yıllığı 2018. Sağlık Bilgi Sistemleri Genel Müdürlüğü, Ankara; 2019.

10. Selçuk M. Çekinik (defansif) tıp, [Yüksek Lisans Tezi]. İzmir Üniversitesi. Sosyal Bilimler Enstitüsü, İzmir; 2015.

11. Özata $M$, Özer $K$, Akkoca Y. Konya il merkezinde çalışan hekimlerde defansif (çekinik) tıp uygulamalarının araştırılması. Gümüşhane Üniversitesi Sağlık Bilimleri Dergisi. 2018; 7(1), 132-139.

12. Başer A, Kolcu G, Çığırgil Y, Kadınkız B, Öngel K. İzmir Karşıyaka ilçesinde görev yapan aile hekimlerinin defansif tıp uygulamaları ile ilgili görüşlerinin değerlendirilmesi. Smyrna Tıp Dergisi. 2014; 77, 16-24.

13. Tancredi LR, Barondess JA. The problem of defensive medicine. American Association for the Advancement of Science. 1978; 200(4344), 879-882.

14. Passmore K, Leung WC. Defensive practice among psychiatrists: A questionnaire survey. Postgraduate Medical Journal. 2002; 78(925), 671-673.

15. Hiyama $T$, Yoshihara $M$, Tanaka $S$, Urabe $Y$, Ikegami $Y$, Fukuhara T, Chayama K. Defensive medicine practices among gastroenterologists in Japan. World Journal of Gastroenterology. 2006; 12(47), 7671-7675.

16. Aynacı Y. Hekimlerde defansif (çekinik) tıp uygulamalarının araştırılması. [Tıpta Uzmanlık Tezi]. Selçuk Üniversitesi, Meram Tıp Fakültesi. Konya; 2008.

17. Vale HM, Miyazaki MC de OS. Defensive medicine: a practice in whose defense? Revista Bioética. 2019; 27(4), 747-755.

18. Banaz M. Hekimlerin defansif tıp ve tıbbi hata tutumlarının incelenmesi. [Yüksek Lisans Tezi]. Hacettepe Üniversitesi Sosyal Bilimler Enstitüsü. Ankara; 2020.

19. Ortashi O, Virdee J, Hassan R, Mutrynowski T, Abu-Zidan F. The practice of defensive medicine among hospital doctors in the United Kingdom. BMC Medical Ethics. 2013; 14(42).

20. Saks M, Landsman S. The paradoxes of defensive medicine. Health Matrix: The Journal of Law-Medicine. 2020; 30(1), 25-83. 